\title{
RETHINKING LEARNING IN THE LIGHT OF DIGITAL TRANSFORMATION AT THE AUSTRIAN SECONDARY COLLEGES FOR AGRICULTURE AND FORESTRY - WHY AND HOW?
}

\author{
Erika Quendler ${ }^{1}$, \& Matthew James Lamb ${ }^{2}$ \\ ${ }^{1}$ Federal Institute of Agricultural Economics, Rural Areas and Mountain Research (Austria) \\ ${ }^{2}$ LKT-TGM Polymer and Environmental Centre Vienna (Austria)
}

\begin{abstract}
The concept of digital transformation has been setting the pace for a while now. It represents one of the most central meta-trends and takes education to a whole new level. Inexorably, the learning environment is becoming increasingly virtual - e.g. Computer Based Training or Web Based Learning, Learning Apps, etc. In order to boost this opportunity properly, there is the need to move beyond merely adding a 'digital' component to traditional teaching. In learning contexts, the idea of 'blending' is not new. Blended learning, nowadays, involves the inclusion of technology-based learning, i.e. providing online or offline activities and materials in the mix, with traditional face-to-face classroom lectures. It is not a wholly new approach to learning and teaching. The practice of including technology-based training has been around since at least the 1960s, first with cassettes, then with videotapes and television, computer and, most recently, the Internet. Given the extent, inevitability and potential of digital transformation there is a clear need to rethink all aspects of learning practices. This ongoing process of digital transformation is inducing changes in the current learning paradigm at secondary colleges for agriculture and forestry, forcing a shift from an instructional system (e.g. face-to-face teaching) to learning experience paradigm. The question of how and whether this process should be shaped, i.e. designing digital learning and flexibly applying technology tools, guides the thinking in this paper. This should not only be applicable for these colleges but transferable. As a starting point his paper looks at the status quo of digitally supported learning at these colleges based on data from an online questionnaire answered by 1,963 pupils. The need for action is clear, from updating the infrastructure and technical standards through changing learning processes to training skill and competence sets for learners and teachers. Reflecting on this data shows that the digital transformation will require the courage to implement more active learning approaches as well as gather experimental experience. Research on current executive development experiences also underpins this development. It is also apparent that by considering the person as a whole any new learning paradigms or perceptions of learning will no longer be restricted to the classroom thanks to digital transformation. This paradigm should form a milestone in 'continuous education' and encompass an 'omnipresent learning environment'. The paper contributes to the ongoing discussion on digital learning (in schools) and the continuous development of a research agenda for learning and teaching in the digital age.
\end{abstract}

Keywords: Digital learning, digital transformation, holistic approach, secondary colleges, agriculture and forestry, Austria.

\section{Introduction}

The rapid development of technology means that the world is increasingly being shaped by the internet and mobile digital devices (e.g. portable devices, social web, digital 3D worlds, digital games, serious gaming). Any future learning digital paradigm will forcibly involve a system of connectivity (Latz and Koutroumpis, 2012, 2), i.e. a system of blended learning. Blended learning, nowadays, involves the inclusion of technology-based learning, i.e. providing online or offline activities and materials in the mix, with traditional face-to-face classroom lectures (Cambridge Dictionary, 2019).

The digital transformation of the learning environment is not just about using digital technology and tools but also about understanding the mechanisms and rules as well as limitations of the digital world as well as adopting them productively and responsibly. More and more teaching material, 
assignments and pupils' work including the taking of final exams is being transformed into digital formats. This results in the need for digital knowledge, skills and competences.

In the light of digital transformation, the question of how teaching and learning with digital media can be practiced and better anchored at the secondary colleges for agriculture and forestry is currently coming to the fore. To what extent is there a need for a guiding holistic approach? Descriptive data of the online survey amongst pupils of these 11 Austrian colleges with a research sample of 1,963 pupils serves as a starting point.

The remainder of the paper is structured as follows. Section 2 outlines the data and methods applied. Section 3 outlines the results of the survey. Section 4 looks at rethinking the learning paradigm. Section 5 concludes with a look at areas for future activity and research.

\section{Data and methods}

The paper is based on select data of the survey 'Digital transformation in Austrian secondary colleges for agriculture and forestry'. The pupils of the 11 colleges could participate in the online survey between 16th and 23rd March 2018. A total of 1,963 questionnaires were completed and evaluated. This corresponds to $53 \%$ of the pupils attending these colleges. The data evaluated was compiled by frequency for the shake of reporting results and drawing conclusions. The results presented are based on an argumentative-deductive research approach. Moreover, the rethinking of the learning system reflects on the survey results by including examples from a literature research.

\section{Survey results - the pupils' opinions}

This section presents the findings by giving a general picture of pupils' feedback on digital transformation at their colleges. For the sake of convenience, it makes sense to bracket the pupils' answers to the survey into two concrete areas: the questions of why and how referring to digital transformation.

For the pupils, digital learning is not merely interesting due to the fact that digital technology, such as desktop PCs and mobile devices, are involved but, according to the survey, digital learning opportunities make sense to them. Not only is this probably because digital media can, in terms of variety of content and media deployed, make lessons more interesting $(87 \%)$ but also because there is a clear reflection of developments in the professional world and therefore the practical aspect is obvious. However, a further point of interest which was clearly shown in the pupils' answers was an awareness of the risks involved in the use of digital technology and media. The pupils see more and more online risks and feel a latent uncertainty when dealing with the internet. The topics of data security and protection are of great importance. The majority of the pupils do not believe in the security of data on the internet. $70 \%$ of the respondents currently assume that their data is unsafe. In this respect, the pupils perceive the unauthorized disclosure of their data and the threat of virus and malicious programs as well as the spying on their data as the biggest risks of internet use. By contrast, the traditional media - radio, television and newspapers (to be purchased) - are rather positively rated by pupils overall. This notwithstanding, the majority $(70 \%)$ of pupils agrees on the importance of learning with digital literacy for their future educational and professional path.

Not surprisingly $57 \%$ of the pupils are in favour of an increased use of digital media in colleges. Moreover, $70 \%$ of pupils think that digital media should be used more diversely, i.e. teachers should try something new more often. In this respect, $78 \%$ of pupils agree that teaching materials should be available digitally. Nevertheless, they advocate a mix of analogue and digital forms of learning (80\%), i.e. a form of blended learning. According to the responses digital technologies and media are aids to make not only the learning, but also the teaching, more pupil-friendly, diverse and modern. Moreover, pupils see digital transformation as a way to enhance their current learning model both within the classroom and without. One in four pupils uses for example social media and blogs for the homework assignments and the preparation of classes outside lesson hours. Integrating technology into the classroom begins with the teacher preparing lessons that use technology in authentic and meaningful situations. Survey results show that $63 \%$ of the pupils say the teachers prepare their class deployment of digital media well. On the other hand, half (49\%) of the pupils believe that teachers should be more interested in using digital media.

\section{Rethinking the learning environment at colleges}

Given the results of the survey, we need to fundamentally rethink our approaches to learning and education - and our ideas of how digital technologies and media can support them. In this regard, the process of the digital transformation of learning should ensure (i) a sufficiently reliable and fast internet 
connection (WLAN network), (ii) the liabilities and responsibilities for the technology have to be defined (iii) the proper and full use of the equipment and (iv) a sustainable upgrading process to guarantee an inventory that is modern and adequate. This is related to the following principles.

What pupils use for learning: The practice of including technology-based training has been around for centuries, first with cassettes, then with videotapes and television, computer and, most recently, the Internet (Web-Based learning). Equipment and software have improved (cf. Moore's Laws). The evolution and the adoption of digital technologies in classrooms, has enabled next-generation learning environments - both physical and virtual - with better connections (e.g. WLAN networks, Chromebooks), easier communication paths (e.g. social media, WebUnits), more robust collaboration capabilities (e.g. blogs solutions, The cloud solutions, G Suite), special training and assessing tools of the learning successes (e.g. asynchronous learning environments, apps for vocabulary training, e-learning platforms, Google Expeditions and Classroom, Open Roperta) and sharing tools (GitHub and Creative Commons). In this context, the teacher is the main person in helping pupils to have access to technological potential by paying attention to individual's needs, talents, interests and differences (cf. Bertelsmann Stiftung, 2015a, b). In doing so, digital transformation can support new learning approaches that engage learners, driving new revenue streams, decreasing operational costs, and preserving and expanding highly valued college brands. (cf. CISCO, 2018, 3f)

How pupils learn: This ongoing process of digital transformation will also contribute not only to the redesign of the classroom (cf. Envision, 2017) but also to a change in the learning system from instructional (e.g. face-to-face teaching with teacher delivering information to a roomful of pupils) to more active learning approaches as well as experimental experience. The possible initiatives of learners are strengthened in two ways: Dialogic participation and democratic negotiation, and creation and sharing of knowledge and digital resources (Sorensen and Brooks, 2017). This entails and comprises the meta-learning output of the learning process in a pupil identity as an active democratic-oriented citizen (Sorensen, 2008). Moreover, it is associated with (a) agency and communicative initiative, (b) digital dialogue and collaborative knowledge construction, (c) open educational resources (OERs). Additionally, we should focus on themes and projects that cut across the disciplines, i.e. combining different disciplines for example maths, science and language, by taking advantage of the rich connections among different domains of knowledge. Furthermore, instead of dividing pupils according to age, we should encourage pupils of all ages to work together on interdisciplinary projects, enabling them to learn from one another and to learn by teaching one another in the sense of a social learning experience (e.g. small group exercises, learning networks). This also includes pupils working on projects for a certain period of time, enabling them to follow through more deeply and meaningfully on the ideas that arise in the course of their work. In this context, the task of education at these colleges is to create a framework for the pupils so that they can perceive, use and actively participate in the opportunities offered by digital transformation in the, and without the, colleges.

What pupils learn: Much of what pupils learn in colleges today was designed for the era of paper-and-pencil. Colleges shall assist pupils in their preparation with the new skills and ideas that are needed for living and working in a digital society. At the same time, the expansion of knowledge associated with the new technologies requires an intensified focus on competence-oriented learning (cf. Albrecht and Revermann, 2016, Sauter, 2018). It is about integration of digital learning and implementing digital tools into the pupils' learning environment in order to gain professional, general, holistic and expansive skills and competences. Against this backdrop, learning success is usually defined as knowledge gain, improved problem-solving ability or better transferability. They are based on the generative theory of multimedia learning (cf. Mayer, 2001), the so-called cognitive load theory (cf. Sweller, 2005) and the LOM Standard (IMS Global Learning Consortium, 2006). Today these set standards in the development of digital learning as done by BMB (2016). More subtly new technologies are changing not only what pupils should learn, but also what they can learn. As new technologies contribute to the change in learning and all parts of our lives, learning to become a better learner is far more important than learning to multiply fractions or memorising the capitals of the world. For example, pupils can now use for example computer simulations or games to explore the workings of systems in the world (everything from ecosystems to economic systems to immune systems) in ways that were previously not possible.

Where and when pupils learn: Although technology and media can never replace the human mind, it can intensify it, and increase the pace of learning. In fact, the digital can include the traditional methods such as providing a learning environment but also make use of the technology to impart knowledge to the pupils. Digital transformation enables learning at any time, at any place, in a variety of ways: alone or in communicative exchange, oriented towards or dissolving classical forms of teaching. There is a need for new concepts for lessons within a digital environment; an example is the integration of a virtual classroom (moodle Adobe Connect). Furthermore, in the years ahead, the Internet as well as 
other digital technologies will open up new learning opportunities, enabling new types of 'knowledge building communities' in which people of all ages around the globe collaborate on projects and learn from one another, e.g. Learning Lab Denmark (http://learninglab.dk/).

The role of teachers: Although digital learning creates new opportunities the role of teachers is still central and irreplaceable, albeit changing. Other roles such as learning tutor, advisor or personal mentor are becoming more important. For example, (i) when working on projects the teacher supports the work in planning work schedules and provides technical support, while the pupils are free to organise their work independently and (ii) the teacher also show pupils that there is a need for practical exercises and not only the digital studying or simulation of learning issues, i.e. applying information and knowledge in practice such as driving a tractor or mowing grass with a scythe. In that way pupils combine mind and heart, realty and emotions, theory and practice as well as training and learning. So pupils are able to become more critical, active and independent learners. This underpins clearly, especially in view of the risks mentioned previously, that the teaching of responsible interaction with and the use of digital media at colleges have to go hand in hand. This can only be done with the help of digital Pedagogy. Digital Pedagogy is a procedure which helps in improving the instructions of the learners. In short this term is an amalgamation of technical information, teaching and understanding of the learners. The values of digital pedagogy are open education, sharing syllabi, sharing teaching resources and self-directed interest based projects. (Christie, 2017, Morris and Stommel, 2015) In this context, teachers should be given the opportunity to acquire these through further education and joint teaching development. It should also be noted that teachers need resources and time for lesson planning and development with digital devices and media.

Values: Digital learning (cf. Park, 2011, Berge and Muilenburg, 2013) provides unique characteristics like portability, user mobility, pervasiveness, ubiquity and immediate interaction with the external environment making the learning experience more engaging and interesting for pupils. Through this constructive confrontation with digital media and their use, the pupils are empowered to use them 'critically and in an emancipatory way' and thereby to develop a 'critical and healthy' attitude towards the media. This will lead to a new paradigm and perception of learning - leading to a strategy - which goes beyond traditional learning in the classroom (see above what pupils learn). This paradigm should form a milestone in 'continuous education' and encompass an 'omnipresent learning environment'. We also have to look at a set of values, such as simplicity, community, mobility, participation, integration, openness and utility that we can use to navigate this rethinking of the learning environment wisely and fruitfully with ethical and moral respect. For progress to endure, it may need a guiding holistic approach based on the needs of the body, mind and soul (Akmençe et al., 2015) within the framework of the given roadmap (Bundeskanzleramt and BMWFW, 2016) and masterplan (BMBWF, n.d.) of digital transformation. This approach should also focus on 'why something needs to be learnt', 'how it is connected to the learner's life' and on 'how it is going to be used in real life' (cf. Akmençe et al., 2015).

\section{Conclusion}

Digital transformation has been, without doubt, changing the learning in colleges, but one cannot say that it has diminished the value of the 'old-school' learning in classrooms. The best part about this digital transformation is that it is combined with the aspects of learning methods, i.e. classroom and online or virtual learning. Eight out of ten pupils advocate a mix of analogue and digital forms of learning. The positive impact of digitally transformed colleges will not come by simply arranging and presenting content in virtualised or even in more personalised ways. Rather, it will come through the synergetic combination of benefits for pupils, teachers as well as these colleges itself, e.g. image factor or further target group with respect to the further educational and professional path, as stated by $70 \%$ of the pupils.

Learning is a process that involves experience, study and teaching that is directed at the whole person paradigm. Therefore, the best approach to learning is one that is holistic. However, a human being is a whole consisting of both matter and sense. In that sense, to achieve perfection in education is to balance the factors including body, mind, soul, feelings and thoughts equally. Its importance gains more value when one thinks about the problems in education in recent years. From this point of view, a holistic approach intends to consider every aspect of the pupils' learning process during their education, so it requires the teacher to notice the pupil's features which are neglected. On the other hand holistic education should improve the pupils not only mentally but also all other aspects.

In order to develop such an approach the following areas of further research emerge: (i) it is paramount to understand the technology skills and knowledge of both teachers and pupils with respect to future employability, to discover their respective needs, and to aim for a mutual understanding of both perspectives (bottom-up), (ii) which human, social, economic or other causes are affected positively as 
well as negatively by the digital transformation and (iii) what personal maxims or priorities are affected by this change in teaching and learning, which are so important that they should be preserved. Beyond that, a sustainable and smart digital transformation within a holistic approach can only succeed if is grounded within the current context of the Austrian education system, and is supported and pushed by the administration and policy (top-down) within the framework of digital transformation of education.

\section{References}

Akmençe, A.E., Akpınar, B., Akmençe, E. (2015). New horizons in education through holistic approach, The Journal of International Lingual, Social and Educational Sciences Year, 1(1), 1-7. Retrieved May 7, 2019, from https://dergipark.org.tr/download/article-file/207650

Albrecht, S., Revermann, Ch. (2016). Digitale Medien in der Bildung. Retrieved May 8, 2019, from http://www.itas.kit.edu/pub/v/2016/real16a.pdf

Berge, Z.I., Muilenburg, L.Y. (2013). Handbook of Mobile Learning. New York: Routledge.

Bertelsmann Stiftung. (2015a). Chancen der Digitalisierung für individuelle Förderung im Unterrichtzehn gute Beispiele aus der Schulpraxis. Retrieved May 8, 2019, from https://www.bertelsmannstiftung.de/fileadmin/files/BSt/Publikationen/GrauePublikationen/Download_IB_10_Praxisbeispiel e_151117.pdf

BMB, Bundesministerium für Bildung. (2016). Bildungsstandards ein Beitrag zur Unterrichts- und $\begin{array}{lllll}\text { Schulentwicklung. } & \text { Retrieved } & \text { May } & 7, & \text { 2019, }\end{array}$ https://bildung.bmbwf.gv.at/schulen/unterricht/ba/bildungsstandards.pdf?6kdmdx

BMBWF, Bundesministerium für Bildung, Wissenschaft und Forschung (n.d.). Masterplan Digitalisierung. $\quad$ Retrieved May $\quad 7, \quad$ from https://bmbwf.gv.at/fileadmin/user_upload/Aussendung/Masterplan_Digitalisierung/Masterplan_D igitalisierung_Presseinformation.pdf

Bundeskanzleramt und BMWFW (2016). Digital Roadmap Austria. Retrieved May 7, from https://www.digitalroadmap.gv.at/fileadmin/downloads/digital_road_map_broschuere.pdf

Cambridge Dictionary (2019). blended learning. Retrieved May 8, from https://dictionary.cambridge.org/dictionary/english/blended-learning

CISCO (2018). The next-generation digital learning environment and a framework for change for education institutions. White paper. Retrieved May 8, from https://www.cisco.com/c/dam/en_us/solutions/industries/docs/education/digital-learningenvironment.pdf

Christie, A. (2017). Building a Toolkit for Digital Pedagogy. Retrieved May 8, from http://www.digitalhumanities.org/dhq/vol/11/3/000310/000310.html

Envision (2017). 6 Key Elements of 21st Century Classroom Design. Retrieved May 7, from https://www.envisionexperience.com/blog/6-key-elements-of-21st-century-classroom-design.

IMS Global Learning Consortium (2006). IMS meta-data best practice guide for IEEE 1484.12.1-2002 standard for learning object metadata. Retrieved May 8, from https://www.imsglobal.org/metadata/mdv1p3/imsmd_bestv1p3.html

Mayer, R.E. (2001). Multimedia Learning. New York: Cambridge University Press.

Morris, S.M., Stommel, J. (2015). Professional Development in Digital Pedagogy. Retrieved May 7, 2019, from http://hybridpedagogy.org/professional-development-in-digital-pedagogy/

Niegemann, H.M., Domagk, S., Hessel, S., Hein, A., Hupfer, M., Zobel, A. (2008). Kompendium multimediales Lernen. Springer Science \& Business Media.

Park, Y. (2011). A pedagogical framework for mobile learning: categorizing educational applications of mobile technologies into four types, Int. Rev. Res. Open Distrib. Learn, 12, 78-102.

Sauter, W. (2018). Die Zukunft des Lernens. Selbstorganisierter Kompetenzerwerb durch personali-siertes Lernen. Gütersloh: Bertelsmann Stiftung. Retrieved May 7, 2019, from https://www.bertelsmann-stiftung.de/de/publikationen/publikation/did/die-zukunft-des-lernens/

Sorensen, E. K (2008). Design of dialogic eLearning-to-learn: metalearning as pedagogical methodology. International Journal of Web Based Communities, 4(2), 244-252

Sorensen E. K., Brooks, E.I. (2017). Designing Inclusive Reflective Learning with Digital Democratic Dialogue Across Boundaries and Diversities. Proceedings of the Design, Learning and Innovation (DLI) conference. Heraklion, Crete, Greece, October 30-31, 2017.

Sweller, J. (2005). Implications of cognitive load theory for multimedia learning. In Mayer, R.E. (Eds.). The Cambridge Handbook of Multimedia Learning. New York: Cambridge University Press, 19-30. 